\title{
Molecular Basis of Age-dependent Gastric Inactivation of Rhesus Rotavirus in the Mouse
}

\author{
Dorsey M. Bass, ${ }^{*}$ Michael Baylor,“ Rosemary Broome, ${ }^{3}$ and Harry B. Greenberg*\| \\ ${ }^{*}$ Departments of Pediatrics and ${ }^{\ddagger}$ Microbiology and Immunology, and the Center for Digestive Diseases, Stanford University, \\ Stanford, California 94305; and the ${ }^{\S}$ Veterinary Medical Unit and "Department of Medicine, \\ Palo Alto Veterans Administration Hospital, Palo Alto, California 94305
}

\begin{abstract}
Rotavirus requires specific proteolytic activation by trypsin for efficient replication in tissue culture. To observe the nature of intestinal proteolytic activation of rotavirus in vivo, metabolically labeled rhesus rotavirus (RRV) grown in the presence of trypsin inhibitors was administered to adult and 10-d-old suckling mice by gavage. In the adult stomach, vp4 was cleaved in a manner distinct from in vitro trypsin cleavage. In the suckling stomach, RRV vp4 remains largely uncleaved. The alternative cleavage in the adult stomach was associated with a profound decrease in viral infectivity. vp4 from RRV recovered from the suckling small intestinal lumen was cleaved in a pattern similar or identical to in vitro trypsin-activated virus with bands comigrating with $\mathrm{vp5}^{*}$ and $\mathrm{vp8*}$. In contrast, vp4 was not observed in any recognizable form in $R R V$ recovered from adult intestines. Comparison of infectivity of virus recovered from suckling and adult intestines revealed a 10,000 -fold decrease in titer in the virus recovered from the adult intestine. In vitro digestions of RRV revealed that pepsin digestion can cleave RRV vp4 and markedly enhance acid-induced loss of rotavirus infectivity. Subsequent digestion with chymotrypsin removes most of the pepsin cleavage products of vp4. Virus injected directly into jejunal loops of adult mice and virus administered orally to adult mice pretreated with antiacid drugs retained infectivity. These studies indicate the development of gastric acid and pepsin secretion may be an important host defense factor in rotavirus gastroenteritis. (J. Clin. Invest. 1992. 89:1741-1745.) Key words: viral enteritis $\bullet$ protease $\bullet$ pathogenesis $\bullet$ host restriction
\end{abstract}

\section{Introduction}

Rotaviruses are an important cause of severe infant gastroenteritis in humans as well as in a variety of other mammals. Symptomatic rotavirus infection usually occurs in young animals; and in some species, such as the mouse, there appears to be an absolute age restriction. In natural infection the virus is transmitted by the fecal-oral route. Thus virions must pass through the stomach en route to their target cells on the villi of the small intestine. During this gastrointestinal luminal phase, infecting virus particles are exposed to a variety of harsh conditions, including various proteases, bile salts, and gastric acid. As with other viruses that replicate in the gastrointestinal tract,

Address correspondence to Dorsey M. Bass, M.D., Division of Pediatric Gastroenterology, Stanford University Medical Center, Room S222, Stanford, CA 94305-511.

Received for publication 23 October 1991 and in revised form 7 January 1992.

The Journal of Clinical Investigation, Inc.

Volume 89, June 1992, 1741-1745 rotavirus has evolved not only to survive these harsh conditions but also to depend on proteolytic activation with trypsin for efficient growth.

Rotaviruses are members of the Reoviridae and consist of 11 double-stranded RNA segments within a bilayered protein capsid. The outer capsid is comprised of two major proteins, vp7 and vp4. vp4 is cleaved by trypsin in vitro, and presumably in vivo, into smaller peptides $\mathrm{vp} 5^{*}$ and $\mathrm{vp} 8^{*}$, which remain associated with the virion (1). This proteolytic cleavage is critical for efficient viral replication both in tissue culture $(2,3)$ and in vivo (4). Although it has long been presumed that intestinal luminal trypsin activates rotavirus in vivo, this has not been directly demonstrated. In this report, vp4 of rhesus rotavirus $(\mathrm{RRV})^{1}$ is shown to be cleaved to products closely resembling $\mathrm{vp} 5^{*}$ and $\mathrm{vp} 8^{*}$ in the infant mouse intestine. In contrast, in the adult mouse, vp4 is first cleaved in the stomach, probably by pepsin, with a resultant striking loss of infectivity. In the adult intestine, further proteolysis, perhaps by chymotrypsin, results in a loss of most of the peptic cleavage product.

\section{Methods}

Animals. Rotavirus-free 8-10-d-old suckling and 6-8-wk-old adult CD1 mice were obtained from Charles River Breeding Laboratories (Portage, MI).

Virus. RRV has been previously described (5). ${ }^{35} \mathrm{~S}$-labeled virus was grown on MA104 cells and purified by fluorocarbon extraction and $\mathrm{CsCl}$ gradient centrifugation as previously described (6), with the modification of adding $0.5 \mathrm{ml} 1 \%$ aprotinin (Sigma Chemical Co., St. Louis, MO) to each $150-\mathrm{cm}^{2}$ flask when the ${ }^{35} \mathrm{~S}$ methionine was added. This allowed us to prepare virus that was largely uncleaved by trypsin.

Oral in vivo proteolysis experiments. Animals were administered $10-100,000 \mathrm{cpm}\left(1-5 \times 10^{6}\right.$ peroxidase focus units [pfu]) of purified ${ }^{35} \mathrm{~S}$-labeled RRV in $50 \mu \mathrm{l}$ of TNC buffer $(10 \mathrm{mM}$ Tris $\mathrm{HCl}, 100 \mathrm{mM}$ $\mathrm{NaCl}, 0.1 \mathrm{mM} \mathrm{CaCl}_{2}$ ) by gavage with stainless steel feeding needles and killed by cervical dislocation 30-60 min later. In some experiments adult mice were pretreated with $5 \mathrm{mg}$ cimetidine orally $1-2 \mathrm{~h}$ before inoculation with labeled RRV. The stomach and small intestine were removed separately and flushed with $2 \mathrm{ml}$ ice-cold TNC buffer. The washes were clarified by centrifugation in a microfuge at $10,000 \mathrm{~g}$ for 5 min at $4^{\circ} \mathrm{C}$, and aliquots were taken for scintillation counting and titration on MA104 cells by peroxidase focus counting as previously described (7). Virus (recovered or inoculum) was not trypsin activated before the titrations. The remainder of the washes were pelleted at $100,000 \mathrm{~g}$ for $1 \mathrm{~h}$ and analyzed by SDS-PAGE (12\% acrylamide) and fluorography. In most experiments, $\sim 30 \%$ (range $15-36 \%$ ) of the administered cpm were recovered in the clarified washes after the low speed centrifugation. Another $20-25 \%$ of administered cpm were recovered with eluted intestinal cells, with most of the remaining administered cpm appearing in the low speed pellet. Intestinal epithelial cells were eluted by incubating the washed intestines everted in $\mathrm{Ca} / \mathrm{Mg}$-free

1. Abbreviations used in this paper: pfu, peroxidase focus units; RRV, rhesus rotavirus; TNC, buffer consisting of $10 \mathrm{mM}$ Tris $\mathrm{HCl}, 100 \mathrm{mM}$ $\mathrm{NaCl}$, and $0.1 \mathrm{mM} \mathrm{CaCl}_{2}$. 
Hanks' buffered salt solution containing $2 \mathrm{mM}$ EDTA for $30 \mathrm{~min}$. The eluted enterocytes were washed four times in cold PBS and aliquots were boiled in Laemmli sample buffer before SDS-PAGE and fluorography. Intestinal and gastric $\mathrm{pH}$ was estimated with $\mathrm{pH}$ paper on undiluted luminal secretions. The accuracy of the $\mathrm{pH}$ paper was verified by comparing results obtained with the paper to those obtained on a pH meter ( $\psi 32$; Beckman Instruments, Inc., Fullerton, CA) on prepared buffers. The $\mathrm{pH}$ paper yielded results within $0.2 \mathrm{pH}$ U of those obtained with the meter.

Jejunal loop experiments. Mice were anesthetized and 2-3-cm jejunal loops were formed by suture ligation, with care to preserve the mesenteric blood supply. The loops were inoculated with $20 \mu \mathrm{l}$ radiolabeled RRV $\left(20,000-40,000 \mathrm{cpm}, 10^{6} \mathrm{pfu}\right)$ in TNC via a 30 -gauge needle. After $1 \mathrm{~h}$, mice were killed while still anesthetized, and the virus was recovered by flushing and centrifugation as described above.

In vitro proteolysis. All proteases were from Sigma Chemical Co. Metabolically labeled virus was suspended in either TNC buffer (pH 7.4) or $1 \times$ standard saline citrate buffer at the $\mathrm{pH}$ indicated. Enzymes were added at a final concentration of $10 \mu \mathrm{g} / \mathrm{ml}$. For sequential digestions, the $\mathrm{pH}$ was adjusted to 7.0 after the initial pepsin digestion by addition of $1 \mathrm{M} \mathrm{NaOH}$ before the addition of the second enzyme. After incubation at $37^{\circ} \mathrm{C}$ for the indicated times, aliquots for titration of infectivity were removed, and the reactions were stopped by addition of Laemmli sample buffer and immediate boiling for $3 \mathrm{~min}$.

\section{Results}

Intraluminal digestion of $R R V$. To examine the gastrointestinal luminal processing of rotavirus, purified radiolabeled RRV was administered to adult and suckling mice by gastric gavage. $1 \mathrm{~h}$ later luminal virus was recovered by flushing the intestines and stomachs with ice-cold TNC buffer. The washes were concentrated by centrifugation and analyzed by SDS-PAGE and fluorography. Fig. 1 depicts the results of a typical experiment. In virus recovered from the stomach of a suckling mouse (Fig. 1 , lane $S S$ ), vp4 was present largely in its uncleaved $86.5-\mathrm{kD}$ form. In virus recovered from the adult stomach (Fig. 1, lane $A S$ ) vp4 was apparently cleaved with a resulting $60-\mathrm{kD}$ band and a faint $\sim 20-\mathrm{kD}$ band. Lane $S I$ depicts virus recovered

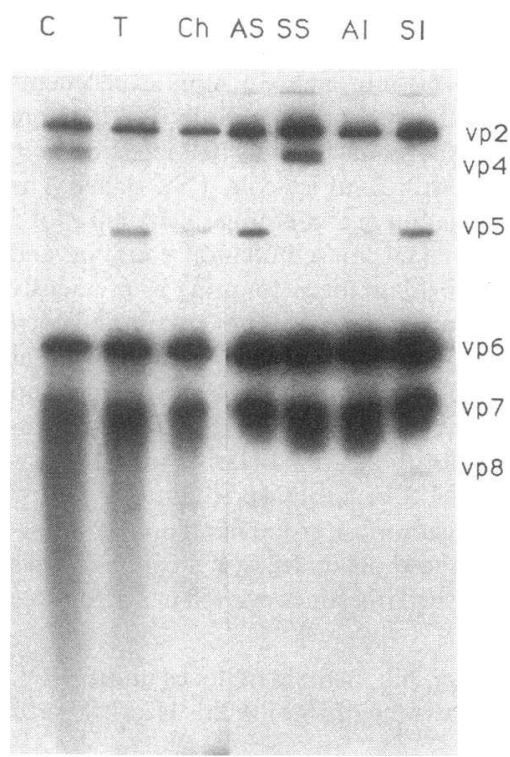

Figure 1. Comparison of ${ }^{35}$ S-labeled RRV recovered from washes of stomachs or small intestines of adult or suckling mice $1 \mathrm{~h}$ after intragastric inoculation. Lane $C$, inoculum RRV; $T, \mathrm{RRV}$ treated in vitro with $10 \mu \mathrm{g} / \mathrm{ml}$ trypsin at $37^{\circ} \mathrm{C}$ for $1 \mathrm{~h}$; Ch, RRV treated in vitro with $10 \mu \mathrm{g} / \mathrm{ml}$ chymotrypsin at $37^{\circ} \mathrm{C}$ for $1 \mathrm{~h} ; A S$, adult stomach; $S S$, suckling stomach; $A I$, adult intestine; $S I$, suckling intestine. Structural viral proteins are identified. The photograph is of a montage of two exposures of the same autoradiograph to optimize visualization of the structural proteins. from the intestine of a suckling mouse in which vp4 is cleaved to $60-$ and $28-\mathrm{kD}$ products similar or identical to $\mathrm{vp} 5^{*}$ and $\mathrm{vp}^{*}$ in in vitro trypsin-digested virus (lane $T$ ). In contrast, virus recovered from adult intestine (lane $A I$ ) was largely devoid of vp4 or its cleavage products.

To ensure that the protein profile of luminal virus reflected that of virus that had attached to its target cells, enterocytes were isolated from the small intestines of mice inoculated with radiolabeled RRV, washed, and analyzed by SDS-PAGE. Again, virus associated with suckling mouse enterocytes (Fig. 2 , lane $S I$ ) demonstrated a profile identical to in vitro trypsinactivated virus with cleavage of $\mathrm{vp} 4$ to $\mathrm{vp} 5 *$ and $\mathrm{vp} 8^{*}$ (lane $T$ ), whereas virus associated with adult mouse enterocytes had a profile lacking identifiable vp4, vp5*, and $v p 8^{*}$ (Fig. 2, lane $A I)$. A single band of $\sim 20 \mathrm{kD}$ is seen in lane $A I$ of Fig. 2 and lane $A S$ in Fig. 1 which may be a fragment of vp4.

Infectivity of recovered virus. To determine whether the altered cleavage of vp4 in the adult mouse gut was associated with changes in infectivity, virus recovered from gastric and intestinal washes was titered on MA104 cells in 96-well plates by a peroxidase focus assay as previously described (7). The results, normalized for cpm recovered (Fig. 3), demonstrated a dramatic fall in titer $(\sim 10,000$-fold $)$ in virus recovered from adult mouse stomach and intestine relative to both inoculum and virus recovered from suckling animals.

Gastric secretions are responsible for the loss of RRV infectivity in the adult mouse. In preliminary experiments, we observed that the gastric $\mathrm{pH}$ in adult and suckling mice differed significantly ( $\mathrm{pH} 2.9$ vs. 3.5, respectively). We hypothesized that developmentally determined changes in gastric secretions might account in part for the dramatic fall in rotavirus titer and the change in vp4 cleavage observed in the adult mouse gastrointestinal lumen. To test this hypothesis, labeled virus was injected into isolated jejunal loops of adult mice, bypassing the gastric lumen. The recovered virus had a normal trypsin-activated protein profile by SDS-PAGE and fluorography (data not shown) and was highly infectious in the peroxidase focus assay (Fig. 4). In fact, the recovered virus was approximately fivefold more infectious than the inoculum, consistent with trypsin-mediated activation of the virus.

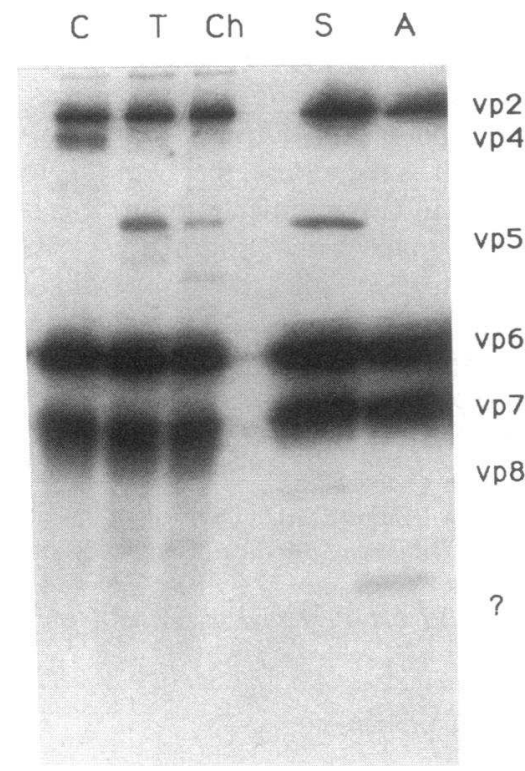

Figure 2. Enterocyte-associated radiolabeled RRV recovered from the small intestines of suckling $(S)$ or adult mice $(A) 1 \mathrm{~h}$ after inoculation. Lane $C$, inoculum RRV; $T$, RRV treated in vitro with 10 $\mu \mathrm{g} / \mathrm{ml}$ trypsin at $37^{\circ} \mathrm{C}$ for $1 \mathrm{~h}$; $C h$, RRV treated in vitro with 10 $\mu \mathrm{g} / \mathrm{ml}$ chymotrypsin at $37^{\circ} \mathrm{C}$ for $1 \mathrm{~h}$. Enterocytes were eluted with 2 mM EDTA from everted intestines and washed four times in PBS before SDS-PAGE and fluorography. 


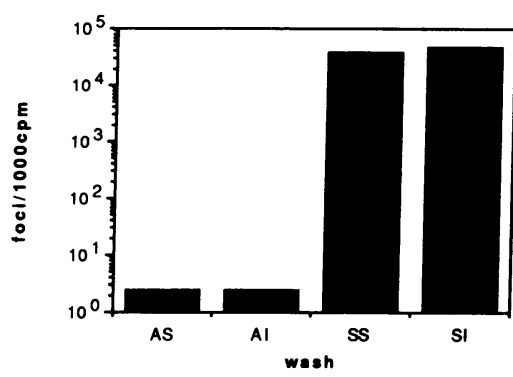
Data presented are means of three animals in each group.

Further evidence for a major role for gastric secretions in the loss of rotavirus infectivity within the adult mouse gastrointestinal tract was obtained by pretreating adult mice with the $\mathrm{H} 2$ receptor antagonist, cimetidine. This treatment resulted in an increase in gastric $\mathrm{pH}$ from $\sim 3.0-3.7$ as determined by $\mathrm{pH}$ paper (data not shown). Fig. 5 shows that, in adult mice pretreated with cimetidine (lane $T$ ), most of the virus recovered from the small intestine had 60- and 28-kD bands, consistent with the products of trypsin-cleaved $\mathrm{vp} 4, \mathrm{vp} 5^{*}$, and $\mathrm{vp} 8^{*}$ (poorly seen). Virus recovered from control animals (lane $C$ ) had no recognizable vp4 or vp4 cleavage products. Results of peroxidase focus assays shown in Fig. 6 confirmed that most of the loss of viral titer could be prevented by decreasing gastric acid secretion with this drug. Similar results were obtained with the proton pump antagonist, omeprazole (data not shown).

In vitro proteolysis. In vitro digestions with several enteric proteases were performed in attempts to duplicate the effects on virus structure and infectivity observed in vivo. Initially, pepsin at various $\mathrm{pH}$ values was used to examine its effects on the structural viral proteins. Fig. 7 shows the results of such an experiment. At $\mathrm{pH}$ values $<2.5$, pepsin digestion resulted in extensive destruction of virtually all of the structural proteins. As the $\mathrm{pH}$ approached 3.0, pepsin digestion resulted in loss of the $\mathrm{vp} 4$ band and the appearance of an $\sim 60-\mathrm{kD}$ band.

In other experiments, digestions with selected proteases either individually or sequentially were performed (Fig. 8). In this experiment, trypsin, pepsin, and chymotrypsin (lanes $T, P$, and $C H$ respectively) digestions were all found to greatly reduce the amount of vp4 in the virions with the simultaneous generation of a new band of $\sim 60 \mathrm{kD}$. In the chymotrypsin digestion there was also the appearance of an $\sim 52-\mathrm{kD}$ band. Trypsin treatment of pepsin-digested virus (lane $P T$ ) resulted in the appearance of yet another band of $80 \mathrm{kD}$, possibly a vp2 cleavage product. Pepsin followed by chymotrypsin treatments (lane $P C$ ) resulted in a substantial reduction of the $60-\mathrm{kD}$ pep-

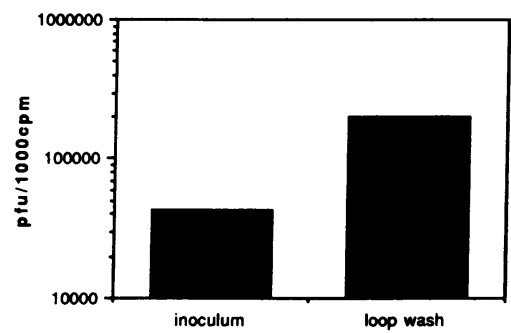

Figure 4. Infectivity of virus recovered from isolated jejunal loops of adult mice. Closed jejunal loops in anesthetized mice were injected with purified radiolabeled RRV $(40,00 \mathrm{cpm}$, $10^{6} \mathrm{pfu}$ ) and recovered by washing after $1 \mathrm{~h}$. Infectivity was deter-

mined by peroxidase focus assay and normalized for cpm recovered. Data presented are means of two experiments.

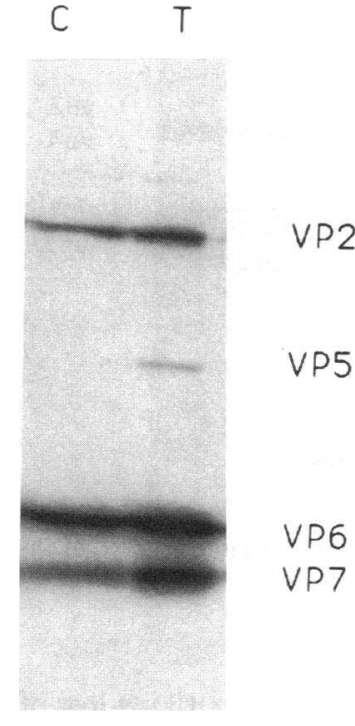

Figure 5. Effects of cimetidine pretreatment on radiolabeled RRV recovered from the small intestine of adult mice. Mice were given $5 \mathrm{mg}$ of cimetidine $(T)$ or saline $(C) 1 \mathrm{~h}$ before intragastric inoculation with radiolabeled RRV.

sin cleavage product, whereas pepsin-trypsin treatment (lane $P T)$ did not.

The infectivity of RRV after in vitro treatment with trypsin, chymotrypsin, pepsin, and pH 3.5 buffer for $1 \mathrm{~h}$ is shown in Fig. 9. As noted previously, trypsin treatment of rotavirus resulted in enhanced infectivity, whereas chymotrypsin treatment had little effect on viral titers. Low $\mathrm{pH}$ treatment reduced titers $\sim 100$-fold from baseline, whereas combined low $\mathrm{pH}$ and pepsin treatment resulted in almost a complete loss of infectivity. In other experiments (data not shown) trypsin-activated RRV infectivity was likewise dramatically reduced by acid/pepsin treatment.

\section{Discussion}

Prior studies in both tissue culture systems and in mice have indirectly suggested the importance of intestinal luminal protease activity in the in vivo replication of rotavirus. In this study we sought to examine directly the luminal proteolytic processing of rotavirus in vivo and to compare such processing in adult and suckling animals. We chose to use the simian rotavirus RRV for these studies because it grows efficiently, can be metabolically labeled to high specific activity, and is able to infect suckling mice and cause diarrheal disease. In our experiments we observed striking differences between suckling and adult mouse enteric luminal processing of rotavirus as well as striking differences in the viability of virus recovered from the gut. These differences appear to be largely due to differences in the adult and suckling mouse gastric secretion.

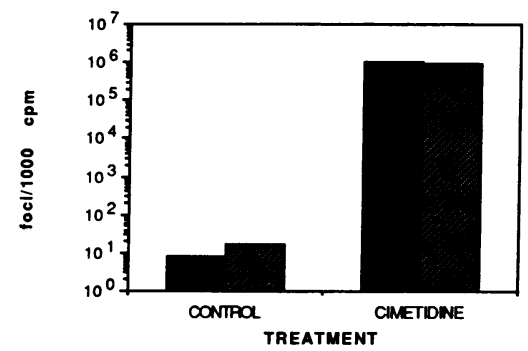

Age-dependent Gastric Inactivation of Rotavirus
Figure 6. Infectivity by peroxidase focus titration of RRV recovered from the small intestines of cimetidine- or saline (control)-treated adult mice $1 \mathrm{~h}$ after inoculation with radiolabeled RRV $\left(5 \times 10^{6} \mathrm{pfu}\right.$, $10,000 \mathrm{cpm})$. Data represent the means of three animals per group. n, Stomach; intestine. 


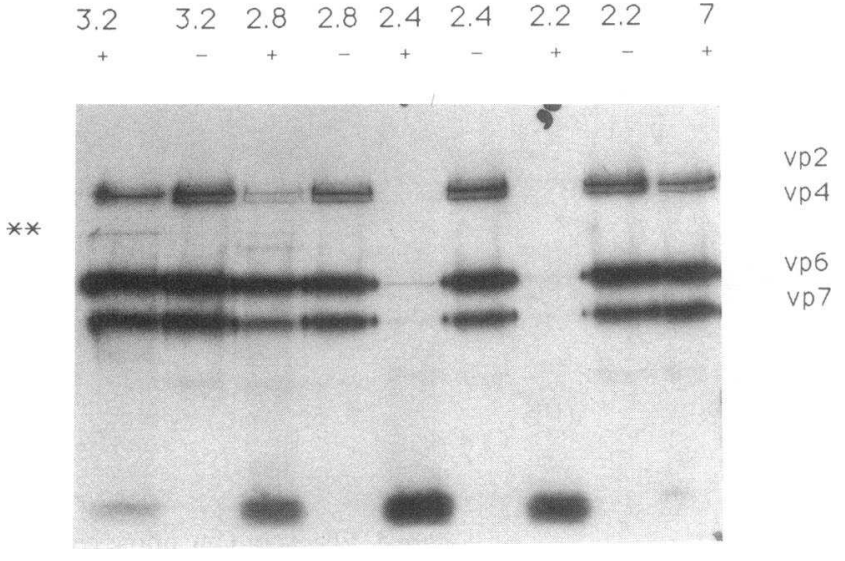

Figure 7. Digestion of radiolabeled RRV with $10 \mu \mathrm{g} / \mathrm{ml}$ pepsin at indicated $\mathrm{pH}$ values. +, pepsin digestion; -, pH buffer control.

In our in vivo experiments, we observed a striking loss of infectivity as RRV traversed the adult mouse stomach. This was associated with a decrease in vp4 content and the appearance of bands of $\sim 60$ and $20 \mathrm{kD}$ (Fig. 1, lane $A S$ ). Although the $60-\mathrm{kD}$ band comigrates vp5* (Fig. 1 , lane $T$ ), it is unlikely to be identical to the product of trypsin digestion of $\mathrm{vp} 4$ for several reasons. First, AS recovered or pepsin-treated virus is not infectious in contrast to trypsin-treated virus (Figs. 3 and 9). Second, the $60-\mathrm{kD}$ band in pepsin-treated virus is susceptible to chymotrypsin degradation (Fig. 8, lane $P C$ ), whereas vp5 is not (Fig. 8, lane $T C$ ). Finally, acid proteases such as pepsin cleave peptides at sites distinct from those utilized by trypsin.

In the intestinal lumen the $60-\mathrm{kD}$ band disappeared. We speculate that the initial cleavage in the adult stomach may be due to pepsin and/or other acid-resistant proteases, as demonstrated in in vitro experiments (Fig. 8, lane $P$ ). The subsequent

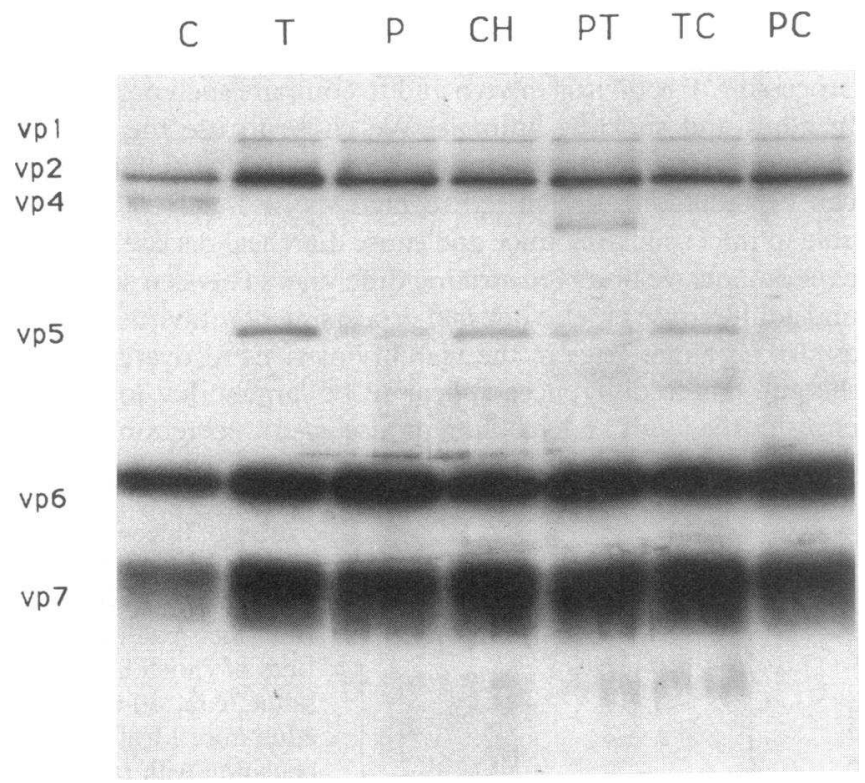

Figure 8. Digestion of radiolabeled RRV with enteric enzymes at 10 $\mu \mathrm{g} / \mathrm{ml}$. $C$, control; $T$, trypsin; $P$, pepsin at $\mathrm{pH} 3.2 ; C H$, chymotrypsin; $P T$, pepsin at $\mathrm{pH} 3.2$ for 30 min followed by trypsin at $\mathrm{pH} 7$ for 30 min; $T C$, trypsin followed by chymotrypsin; $P C$, pepsin at $\mathrm{pH} 3.2$ for 30 min followed by chymotrypsin at $\mathrm{pH} 7.0$ for $30 \mathrm{~min}$.

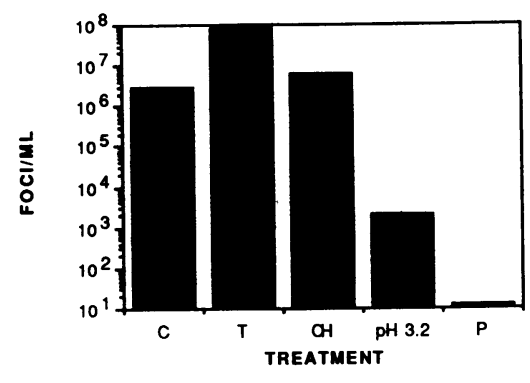

Figure 9. Infectivity of RRV after in vitro digestion. RRV was digested with $10 \mu \mathrm{g} / \mathrm{ml}$ of the protease for $1 \mathrm{~h}$ before titration by peroxidase focus assay. $C$, control; $\mathrm{T}$, trypsin; $\mathrm{CH}$, chymotrypsin; all in 3.2, $\mathrm{SSC}$ buffer at $\mathrm{pH}$ 3.2; $P$, pepsin in SSC buffer $\mathrm{pH} 3.3$. TNC buffer at $\mathrm{pH}$ 7.0.

loss of the $60-\mathrm{kD}$ band in the intestine is probably a result of intestinal lumenal proteases such as chymotrypsin, as seen in our in vitro studies (Fig. 8, lane $P C$ ). Such a loss of a $60-\mathrm{kD}$ fragment of vp4 from SA11 has been previously observed with high dose chymotrypsin treatment (1). The cleavage of vp4 by pepsin in vitro and in vivo correlates with the observed loss of RRV infectivity. It is tempting to speculate that changes in vp4, which contains neutralizing epitopes, mediates hemagglutination, and probably mediates cell attachment and penetration, could lead to a loss of infectivity. The lack of viral inactivation in adult intestinal loops (Fig. 4) or in cimetidine-treated animals (Fig. 6) argues against inactivation of RRV in the adult intestinal lumen.

Several previous studies have examined the interaction of rotavirus with various proteases. Early work demonstrated enhancement of rotavirus growth in the presence of trypsin and demonstrated that the effect was on the viral particle rather than on host cells (8). Trypsin activation of rotavirus is associated with the cleavage of the outer capsid protein vp4 into $\mathrm{vp5}{ }^{*}$ and $\mathrm{vp} 8 *(1)$. We observed an identical cleavage of intact vp4 in the murine small intestine (Figs. 1 and 5). Chymotrypsin, another intestinal luminal protease, fails to activate rotavirus and cleaves vp4 into a fragment of similar electrophoretic mobility to $\mathrm{vp} 5^{*}$ and several fragments of lower molecular weight than $v p 8^{*}(1,9,10)$.

The mechanism by which trypsin cleavage of $\mathrm{vp} 4$ mediates enhanced infectivity is not definitely known, although some studies have proposed that it facilitates viral penetration of target cell membranes $(7,11)$. Experiments using MAbs specific for the $v p 8^{*}$ product of vp4 have suggested that $\mathrm{vp} 8 *$ may be involved in cell attachment (12).

Although it has long been hypothesized that the effects of trypsin on rotavirus growth in tissue culture parallel events in the intestinal lumen, little direct evidence has been produced to date. Protease inhibitor studies indirectly demonstrated the importance of intestinal luminal proteolysis for rotavirus replication in vivo (4). By methods previously used to study the intestinal lumenal activation of reovirus $(13,14)$, we have directly demonstrated the cleavage of rotavirus vp4 into $\mathrm{vp} 5^{*}$ and $\mathrm{vp} 8^{*}$ in the suckling mouse intestine. Similar cleavage and activation of infectivity were observed in the adult mouse intestine only if gastric secretions were physically bypassed or pharmacologically suppressed.

Several previous workers have examined the inactivation of rotaviruses by acid and gastric secretions (15-17). Although methodologies differ, most have shown rotaviruses to be relatively stable at $\mathrm{pH}>4$ and with inactivation half-lives of 10 $100 \mathrm{~min}$ at $\mathrm{pH} 3$. We observed a comparable drop in infectivity of RRV in vitro at $\mathrm{pH} 3.5$, which was greatly enhanced in the presence of pepsin (Fig. 9). Pepsin has previously been shown 
to inactivate serotype 1 reovirus in association with the removal of $\sigma 3$ (13). At $\mathrm{pH}$ values of $<3$, we found that pepsin digestion resulted in proteolysis of the entire particle (Fig. 7). Indeed, we have found that, at $\mathrm{pH}$ values $<2.5, \mathrm{RRV}$ rapidly loses infectivity and hemagglutination titer whether or not pepsin is present (data not shown). These data are consistent with previous morphological studies in which collapse of the rotavirus outer capsid was observed at low $\mathrm{pH}$ values (18). The nonfasting gastric $\mathrm{pH}$ in our suckling mice was $\sim 3.5$, whereas in the adult mouse stomach it was $\sim 3.0$. These values may not reflect the microenvironment of rotavirus particles in the stomach, where foodstuffs may locally buffer the gastric $\mathrm{pH}$.

The differences noted between the effects of gastric secretions from adult and suckling mice on RRV infectivity are consistent with previously observed differences in acid and pepsin secretion in the developing rodent (19). Rodents generally have very low acid and pepsin secretion until the time of weaning. It has been proposed that this reduced secretion facilitates the enteric absorption of functional maternal antibodies from breast milk.

It seems doubtful that the enhanced gastric acid/pepsin secretion noted in the adult mice is the sole determinant of the strict host age restriction for symptomatic rotavirus disease in the murine model. If rotavirus replication were highly efficient in the adult mouse small intestine, one would expect disease to occur even if only a few infectious virions succeeded in surviving the gastric $\mathrm{pH}$ barrier. We were able to detect small amounts of infectious virus in the small intestines of untreated adult mice (Fig. 3). In preliminary studies using cimetidinetreated, seronegative adult mice inoculated with $10^{7} \mathrm{pfu}$ of $R R V$, we have observed more frequent excretion of rotavirus measured by ELISA of fecal suspensions in treated (4/6) versus control mice (1/4) but no evidence of diarrhea in any mouse. Thus, other factors affecting the efficiency of rotavirus replication in the intestine, such as a relative paucity of viral receptors on adult enterocytes $(20,21)$, or affecting the expression of overt disease, such as increased intestinal absorptive reserve in adult mice, must also be important in host age restriction of rotavirus diarrhea.

Although humans do increase their capacity to secrete both acid and pepsin as they mature, the most significant increases occur during the first three months of life (22), before the peak age for rotavirus disease. The reduced gastric acid observed in human neonates might account for the persistence of low virulence strains of rotavirus in some nurseries (23).

It seems likely that gastric inactivation of rotavirus virions is an important host defense mechanism in natural infections. A study of the minimal infective dose of rotavirus strain OSU in piglets detected gastric secretion factor(s) that reduced the infectivity of the inoculum and were both $\mathrm{pH}$ and concentration dependent (15). Human vaccine studies using RRV and RIT 4237 rotavirus strains demonstrated that a higher proportion of infants responded to the vaccine if they were pretreated with bicarbonate buffer $(24,25)$. Greatly reduced gastric acid and pepsin secretion have been observed in malnourished and even well-nourished children in developing countries $(26,27)$. This reduced gastric acid barrier may well predispose these children to rotavirus as well as other enteric infections.

\section{Acknowledgments}

This work was supported by Public Health Service grant R22-AI21362, Digestive Disease Center grant DK-38707, and an American Gastroenterological Association Industry Scholar award to D. M. Bass.

\section{References}

1. Estes, M. K., D. Y. Graham, and B. B. Mason. 1981. Proteolytic enhancement of rotavirus infectivity: molecular mechanisms. J. Virol. 39:879-888.

2. Matsuno, S., S. Inouye, and R. Kono. 1977. Plaque assay of neonatal calf diarrhea virus and the neutralizing antibody in human sera. J. Clin. Microbiol. 5:1-6.

3. Barnett, B. B., R. S. Spendlove, and M. L. Clark. 1979. Effect of enzymes on rotavirus infectivity. J. Clin. Microbiol. 10:111-113.

4. Vonderfecht, S. L., R. L. Miskuff, S. B. Wee, S. Sato, R. R. Tidwell, J. D. Geratz, and R. H. Yolken. 1988. Protease inhibitors suppress the in vitro and in vivo replication of rotavirus. J. Clin. Invest. 82:2011-2016

5. Greenberg, H. B., J. Valdesuso, W. K. van Wyke, K. Midthun, M. Walsh, V. McAuliffe, R. G. Wyatt, A. R. Kalica, J. Flores, and Y. Hoshino. 1983. Production and preliminary characterization of monoclonal antibodies directed at two surface proteins of rhesus rotavirus. J. Virol. 47:267-275.

6. Bass, D. M., E. R. Mackow, and H. B. Greenberg. 1990. NS35 and not vp7 is the soluble rotavirus protein which binds to target cells. $J$. Virol. 64:322-330.

7. Kaljot, K. T., R. D. Shaw, D. H. Rubin, and H. B. Greenberg. 1988. Infectious rotavirus enters cells by direct cell membrane penetration, not by endocytosis. J. Virol. 62:1136-1144.

8. Clark, S. M., J. R. Roth, M. L. Clark, B. B. Barnett, and R. S. Spendlove. 1981. Trypsin enhancement of rotavirus infectivity: mechanism of enhancement. J. Virol. 39:816-822.

9. Kitaoka, S., H. Suzuki, T. Sato, Y. Numazaki, T. Konno, and N. Ishida. 1987. Failure in chymotrypsin enhancement of human rotavirus infectivity. To hoku J. Exp. Med. 151:127-128.

10. Sato, T., S. Kitaoka, H. Suzuki, T. Konno, and N. Ishida. 1987. Effect of trypsin and chymotrypsin on polypeptides of human rotavirus KUN strain. Med. Microbiol. Immunol. 176:65-73.

11. Mackow, E. R., R. D. Shaw, S. M. Matsui, P. T. Vo, M. N. Dang, and H. B. Greenberg. 1988. The rhesus rotavirus gene encoding protein VP3: location of amino acids involved in homologous and heterologous rotavirus neutralization and identification of a putative fusion region. Proc. Natl. Acad. Sci. USA. 85:645-649.

12. Ruggeri, F. M., and H. A. Greenberg. 1991. Antibodies to the trypsin cleavage peptide $\mathrm{vp} 8^{*}$ neutralize rotavirus by inhibiting binding of virions to target cells in culture. J. Virol. 65:2211-2219.

13. Bass, D. M., D. K. Bodkin, R. Dambrauskas, J. S. Trier, B. N. Fields, and J. L. Wolf. 1990. Intraluminal proteolytic activation plays an important role in replication of type I reovirus in the intestines of baby mice. J. Virol. 64:1830-1833.

14. Bodkin, D. K., M. L. Nibert, and B. N. Fields. 1989. Proteolytic digestion of reovirus in the intestinal lumens of neonatal mice. J. Virol. 63:4676-4681.

15. Graham, D. Y., G. R. Dufour, and M. K. Estes. 1987. Minimal infective dose of rotavirus. Arch. Virol. 92:261-271.

16. Estes, M. K., D. Y. Graham, E. M. Smith, and C. P. Gerba. 1979. Rotavirus stability and inactivation. J. Gen. Virol. 43:403-408.

17. Weiss, C., and H. F. Clark. 1985. Rapid inactivation of rotaviruses by exposure to acid buffer or acidic gastric juice. J. Gen. Virol. 48:109-114.

18. Palmer, E. L., M. L. Martin, and F. A. Murphy. 1977. Morphology and stability of infantile gastroenteritis virus: comparison with reovirus and bluetongue virus. J. Gen. Virol. 35:403-414.

19. Johnson, L. R. 1985. Functional development of the stomach. Annu. Rev. Physiol. 85:1201-1219.

20. Bass, D. M., E. Mackow, and H. B. Greenberg. 1991. Identification and partial characterization of a rhesus rotavirus binding glycoprotein on murine enterocytes. Virology. 183:602-610.

21. Riepenhoff, T. M., P. C. Lee, P. J. Carmody, H. J. Barrett, and P. L. Ogra. 1982. Age-dependent rotavirus-enterocyte interactions. Proc. Soc. Exp. Biol. Med. 170:146-154.

22. Wershil, B. K. 1991. Gastric Function. In Pediatric Gastrointestinal Disease. W. A. Walker, P. R. Durie, J. R. Hamilton, J. A. Wilkes-Smith, and J. B. Watkins, editors. B.C. Decker Inc., Philadelphia. 256-265.

23. Gorziglia, M., Y. Hoshino, W. A. Buckler, I. Blumentals, R. Glass, J. Flores, A. Z. Kapikian, and R. M. Chanock. 1986. Conservation of amino acid sequence of VP8 and cleavage region of $84-\mathrm{kDa}$ outer capsid protein among rotaviruses recovered from asymptomatic neonatal infection. Proc. Natl. Acad. Sci. USA. 83:7039-7043. [Published erratum appears in Proc. Natl. Acad. Sci. USA. 84:2062.]

24. Vesikari, T., E. Isolauri, E. D'Hondt, A. Delem, and F. E. Andre. 1984. Increased "take" rate of oral rotavirus vaccine in infants after milk feeding. Lancet. ii:700. (Letter)

25. Pichichero, M. E., G. A. Losonsky, M. B. Rennels, F. A. Disney, J. L. Green, A. B. Francis, and S. M. Marsocci. 1990. Effect of dose and a comparison of measures of vaccine take for oral rhesus rotavirus vaccine. The Maryland Clinical Studies Group. Pediatr. Infect. Dis. J. 9:339-344.

26. Gracey, M. 1982. Intestinal microflora and bacterial overgrowth in early life. J. Pediatr. Gastroenterol. Nutr. 1:13-22.

27. Gilman, R. H., R. Partanen, K. H. Brown, W. M. Spira, S. Khanam, B. Greenberg, S. R. Bloom, and A. Ali. 1988. Decreased gastric acid secretion and bacterial colonization of the stomach in severely malnourished Bangladeshi children. Gastroenterology. 94:1308-1314. 